\title{
Quantification of Environmental Flow Requirement for some Rivers in West Java
}

\author{
Waluyo Hatmoko ${ }^{1,{ }^{*}}$, Levina $^{1}$, Radhika $^{1}$, Amirwandi $^{1}$, and Rendy Firmansyah ${ }^{1}$ \\ ${ }^{1}$ Research Center for Water Resources, Jalan Ir. H. Juanda 193, Bandung 40135, Indonesia
}

\begin{abstract}
Sustainable Development Goal (SDG). Water management is making a balance between water for livelihood and water as a resource. Environmental Flow Requirement (EFR) is water conservation, on the side of the water for livelihood, to sustain the river ecosystem. In Indonesia, the common quantification of EFR is dependable flow Q95\%. However, there are alternative quantities: a) Guideline of irrigation states that $5 \%$ from the available water in the river is for environmental purposes; b) Adoption of the Tennant Method of using $10 \%$ of the mean flow; and recently Food and Agriculture Organization (FAO) in the framework of SDG proposed that in Java Island the EFR is from $40 \%$ to $50 \%$ of the mean annual flow. This paper discusses several ways of quantification of the EFR in Indonesia, and apply the different EFR quantities to Citarum, Cimanuk, and Cimandiri Rivers in West Java. It is concluded that EFR quantity according to FAO that might be suitable for the rivers in the pristine catchments in the southern part of West Java is too high for the rivers in the northern part of West Java which is heavily populated and maturely developed. Furthermore, the dependable flow of Q95\% is found to be close to the quantity of FAO, but in the dry season, Q95\% is more suitable. It is recommended using a modified FAO that combine with Q95\% during the dry season.
\end{abstract}

\section{Introduction}

Water plays an important part in the seventeen goals of the Sustainable Development Goal (SDG). Water management is making a balance between water for livelihood and water as a resource. Environmental Flow Requirement (EFR) is water conservation, on the side of the water for livelihood, to sustain the river ecosystem.

Water demands include needs for households, urban and industrial, irrigation, electric power, navigation, as well as water needs for recreation, fisheries, and wildlife. The latter water needs can be interpreted as the need for water for the environment or maintenance of river flow (Goodman \& Major, 1984). The Study Guidelines for the PSA Irrigation Project 01 (Ditjen Pengairan, 1986) have also included the need to maintain streams for endangered species.

In Indonesia, some of the rivers are already heavily exploited for domestic, municipal and industrial (DMI) as well as irrigation water demand. Some of the rivers left very little water in the rivers as EFR. Currently, the dependable flow of $95 \%$ is applied as EFR, and some water users consider it as too high.
This paper discusses several ways of quantification of the EFR in Indonesia, and apply the different EFR quantities to Citarum, Cimanuk, and Cimandiri Rivers in West Java. The objective of this study is to find the most appropriate EFR in West Java, Indonesia.

\section{Study Location and Methods}

\subsection{Study Location}

The location of the study is the three rivers in West Java, Indonesia namely: Citarum, Cimanuk, and Cimandiri Rivers, and their River Basin Territory (RBT): Citarum, Cimanuk-Cisanggarung, and Cisadea-Cibareno respectively. The location of these river basin territories with their corresponding river gauging stations is shown in Figure 1.

The coordinates and the statistical characteristics of the above-selected rivers in West Java are presented at the following table.

\footnotetext{
* Corresponding author: whatmoko@gmail.com
} 
Table 1 Coordinates and statistical characteristics of the river gauging stations

\begin{tabular}{|l|l|r|r|r|r|r|}
\hline No. & Rivers & Lattitude & Longitude & $\begin{array}{c}\text { Mean } \\
(\mathrm{cms})\end{array}$ & $\begin{array}{c}\text { Standard } \\
\text { Deviation } \\
(\mathrm{cms})\end{array}$ & $\begin{array}{c}\text { Coefficient } \\
\text { of Variation }\end{array}$ \\
\hline 1. & Citarum-Nanjung (Citarum RBT) & 6.9417 & 107.5361 & 75.0 & 52.0 & 0.69 \\
\hline 2. & Cimanuk-Tomo (Cimanuk-Cisanggarung RBT) & 6.7667 & 108.1333 & 90.7 & 73.1 & 0.81 \\
\hline 3. & Cimandiri-Tegaldatar (Cisadea-Cibareno RBT) & 7.0069 & 106.7786 & 18.0 & 11.6 & 0.64 \\
\hline
\end{tabular}

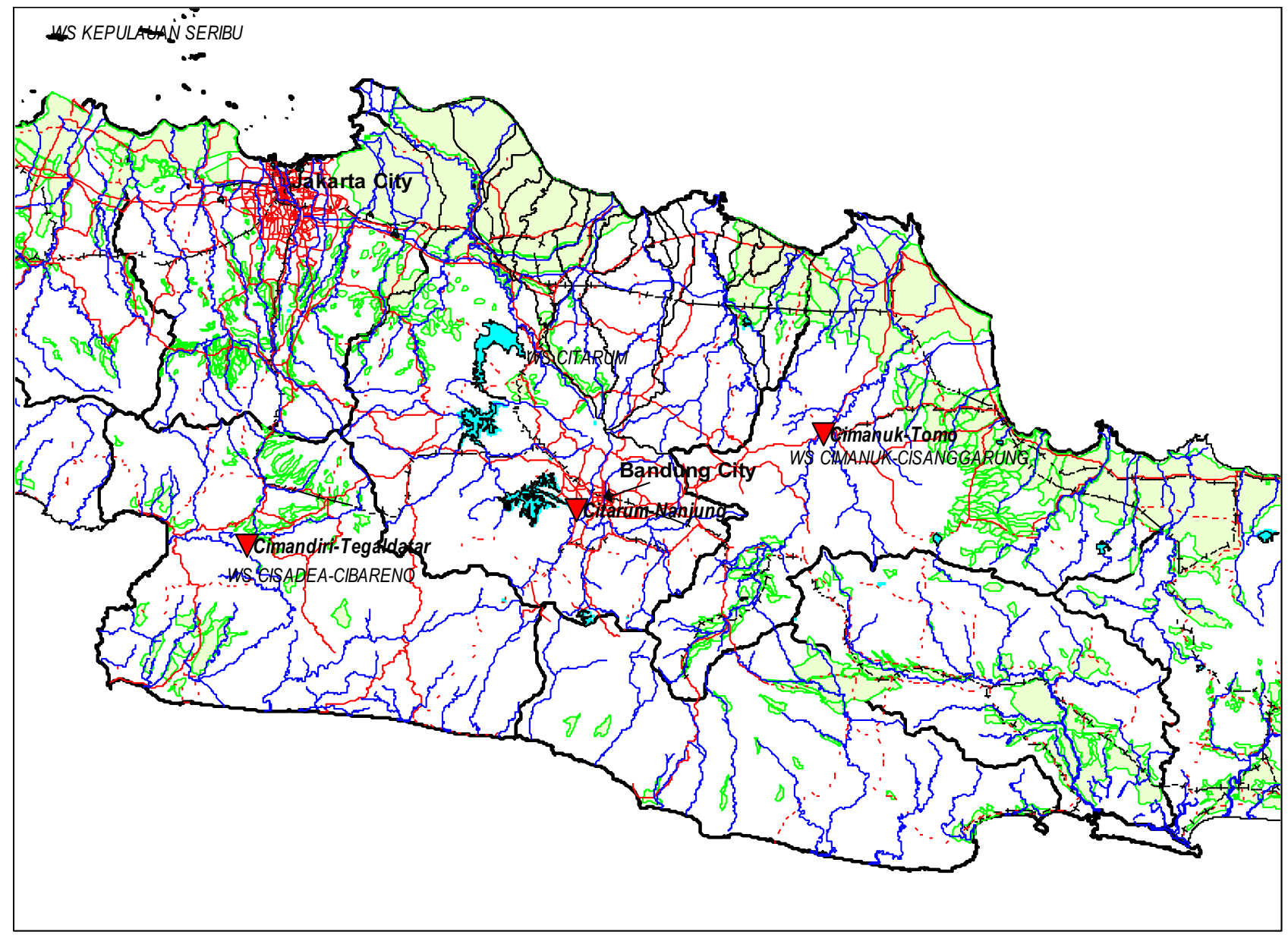

Fig. 1. Location of the three river basin territories with corresponding river gauging stations

\subsection{General Methodology}

The methodology of quantification and finding the appropriate EFR for rivers in West Java is as follows:

1) Inventory of the available EFR methods in Indonesia;

2) Quantify the different available EFR methods for Citarum, Cimanuk, and Cimandiri Rivers;

3) For each of the three rivers studied, compute the water availability and water demands for domestic, municipal and industrial (DMI), and irrigation water demand for their corresponding river basin territory namely: Citarum, Cimanuk-Cisanggarung, and Cisadea-Cibareno River Basin Territory. Assess the impact of the EFR implementation policy on water balance and water allocation for DMI and irrigation sectors.
4) Propose the appropriate EFR for the rivers in the study area.

\subsection{Inventory of EFR Criteria in Indonesia}

In Indonesia, the common quantification of EFR is dependable flow Q95\% with some different perception on its implementation: twelve Q95\% of monthly flows; a single Q95\% from the whole data; and a single value from minimum monthly Q95\%. The high value of EFR motivates the search for other criteria: a) Guideline of irrigation states that $5 \%$ from the available water in the river is for environmental purposes, and b) Adoption of the Tennant Method of using $10 \%$ of the mean flow. Recently Food and Agriculture Organization (FAO) in the framework of SDG suggests that in Java Island the EFR is from $40 \%$ to $50 \%$ of the mean annual flow. 


\subsubsection{Dependable flow $95 \%$}

Government Regulation No. 38 of 2011 concerning River, which has been canceled by law because of its parent namely Law no. 7 of 2004 concerning Water Resources has been canceled, stating that the magnitude of river maintenance discharge of $95 \%$. The magnitude of the maintenance flow of this river is equivalent to a 20 yearly dry discharge, a relatively small number, but in river areas where maximum resource utilization is seen it can lead to conflicts of interest with other water users.

Indonesian regulation number 38 in the year 2008 about river state that river maintenance flow of dependable $95 \%$ should be available at all river reach all the time. By the abolishment of Water Law 11/2004 makes the regulation 38 is not valid anymore. However, there is a ministerial guideline mentioning the river maintenance flow of dependable flow $95 \%$. The guideline is still not yet clear how the Q95\% is calculated. There are three methods of computing Q95\%: a) Q95\% Annual, one number Q95\% from all of the data and apply for all of the time; b) Q95\% Seasonal, every month in a year, the Q95\% is calculated and applied for this particular month; and c) Q95\% Low, Similar method with b), but only apply the minimum value from the 12 month Q95\% values.

\subsubsection{Tennant Method}

The weakness of the Q95\% mainstay approach is that rivers with natural catchment conditions generally have relatively small fluctuations and as a result, the Q95\% value becomes large approaching $\mathrm{Q} 80 \%$ and average discharge. To avoid this, we can use the Tennant Method (Shaeri Karimi, Yasi, \& Eslamian, 2012) where the amount of maintenance flow is expressed as a percentage of the average river flow discharge, with a minimum percentage value of $10 \%$ of the average discharge. To adjust the EFR value to the seasonal discharge fluctuation, this $10 \%$ of average discharge is applied for each month in a year.

\subsubsection{Irrigation Criteria Guideline (KP-02)}

The KP-02 Irrigation Planning Guideline states that in the interests of environmental balance and regional needs downstream of the main building, the river water flow is not permitted to be tapped in its entirety, but must continue to flow as much as $5 \%$ of the existing discharge (Pengairan, 1986). This EFR of 5\% from the river flow is applied for each month in a year to bring the EFR proportionally with the average monthly flow in a year.

\subsubsection{Sustainable Development Goal (SDG)}

SDG states that the need for environmental flow or environmental requirements flow (ERF) is around $40 \%$ $50 \%$ of the annual average discharge (FAO, 2019). This EFR is very important because it affects the level of water stress whose formula is:

$\mathrm{WSI}=\mathrm{TWW} /(\mathrm{TWRR}-\mathrm{EFR})$

with:

WSI $=$ Water Stress Indicator, an indicator of water stress

TWW = total water withdrawn, total water withdrawal, total water use for irrigation, urban and industrial households, installed capacity of natural resource infrastructure

TRWR $=$ total renewable water resources, availability of renewable water (surface water plus shallow groundwater)

$\mathrm{EFR}=$ environmental flow requirements, environmental water requirements

EFR depends on environmental management classes (Sood et al., 2017). Classes A and B represent the unmodified and largely natural conditions, with no or limited modification, has occurred or should be allowed. Class $\mathrm{C}$ is moderately modified, where the modifications are such that they generally have a limited impact on ecosystem integrity. Most of the rivers in Indonesia are in class B and C, and in Java in class C with EFR of $40 \%$ to $60 \%$ of the mean annual flow.

\section{Results and Discussions}

\subsection{Quantity EFR}

The computation result of WSI for the three locations is presented in the following table. The EFR values for the methods of Q95\% Seasonal, Tenant, and KP-02 are presented as the range from the minimum to the maximum value. Which EFR method is selected depending on the stakeholders in the river basin. The environmentally conscious stakeholders would prefer a large number of EFR, while water users prefer the small value of EFR to have enough water for their water requirement fulfillment.

These EFR results are verified by comparing its value with the average river flow value at each location in the following discussions.

Table 2 EFR values for the three location

\begin{tabular}{|r|l|c|c|c|c|c|c|}
\hline \multirow{2}{*}{ No. } & \multirow{2}{*}{ River Basin Territory } & \multicolumn{5}{|c|}{ Environmental Flow Requirement (m3/s) } \\
\cline { 3 - 9 } & & Q95\% Seasonal & Q95\% Annual & Q95\% Low & Tenant & KP-02 & SDG \\
\hline 1 & Citarum & $5.2-67.3$ & 7.7 & 5.2 & $2.3-12.8$ & $1.2-6.4$ & 45.1 \\
\hline 2 & Cimanuk-Cisanggarung & $0.3-72.1$ & 5.9 & 0.3 & $2.8-15.2$ & $1.4-7.6$ & 90.7 \\
\hline 3 & Cisadea-Cibareno & $0.2-70.1$ & 5.6 & 0.2 & $4.4-32.7$ & $2.2-16.4$ & 104.1 \\
\hline
\end{tabular}




\subsection{Comparison of EFR}

A comparison of different EFR criteria can be made annually and monthly. Comparison is made on all possible EFR criteria by examining their proportion from mean flow. This approach is also a means to verify the resulting EFR that should be somewhere between the minimum value of flow to the about the average flow as in the SDG method.

\subsubsection{Annual proportion of EFR}

The following figure shows the annual proportion of water should be made available for EFR on six different EFR criteria.

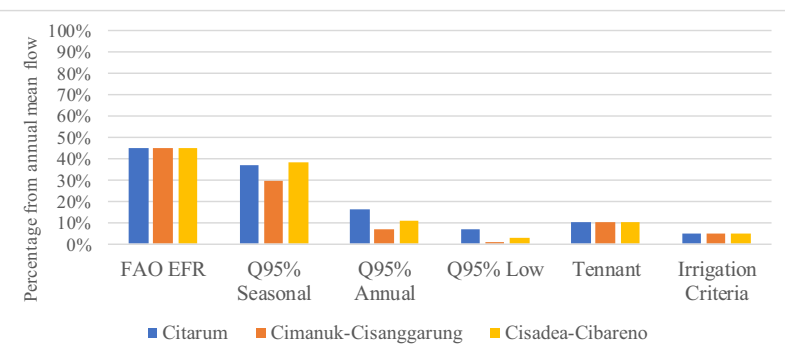

Fig. 2. The proportion from the annual mean flow of the different criteria for Environmental Flow Requirement

A comparison of different EFR in fig 2 shows that EFR, as suggested by FAO, reaches the highest proportion of mean annual flow. The seasonal dependable flow Q95\% is almost as high as the FAO EFR. This seasonal Q95\% is having large EFR due to the fact that during the rainy season the Q95\% is also much higher than the dry season.

\subsubsection{Monthly proportion of EFR}

Monthly EFR as a proportion from the monthly flow is presented in Figure 3 and Figure 4 for Citarum and Cimanuk River respectively. In both figures the EFR for SDG suggested by FAO are having the same proportion of $45 \%$. The same also applies to Tennant Method and Irrigation Criteria by definition are having a proportion of $10 \%$ and $5 \%$ respectively.

The dependable flow of seasonal monthly $95 \%$ is different on Citarum and Cimanuk River. In Cimanuk River with higher fluctuation of flow reflected in a higher coefficient of variation is having very low Q95\% during the dry season, to about $5 \%$ of the mean monthly flow in the driest month. On the other hand, the more stable Citarum River is having Q95\% of as high as 15\% from the mean flow in the driest month.

The constant value over all the time of EFR Q95\% annual from all the data series and EFR was taken from a minimum Q95\% from the twelve months show a higher proportion to mean monthly flow during the dry season. This condition is conducive and suitable for rivers already having high water usage.

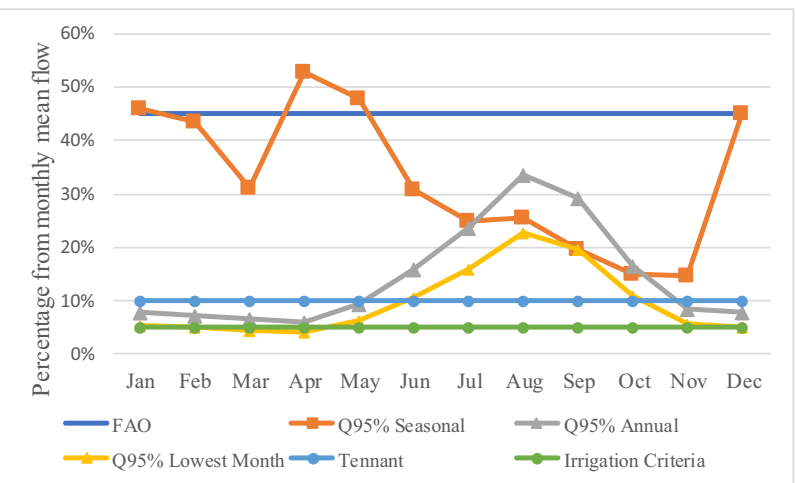

Fig. 3. The proportion of EFR to monthly mean flow in the Citarum River

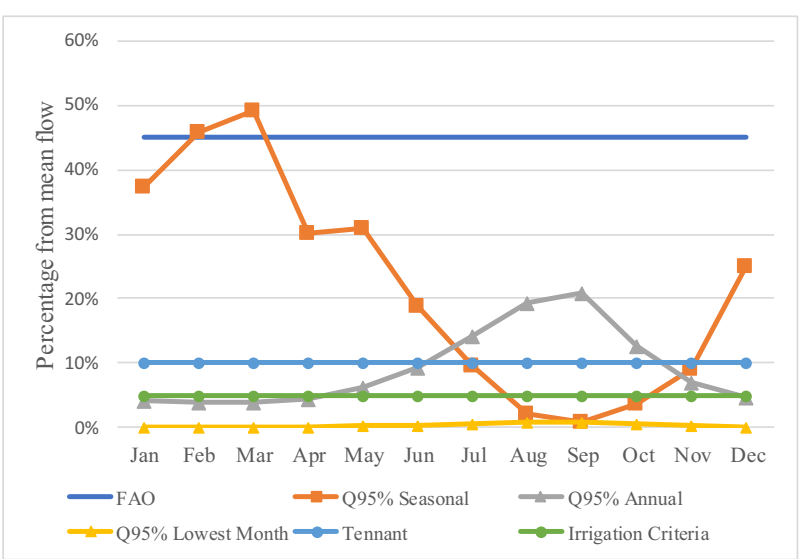

Fig. 4. The proportion of EFR to monthly mean flow in the Cimanuk River

\subsection{EFR impact on other water users}

Assessing the impact of EFR on other water users is carried out by calculating the water balance in the RBT. The data on available water and dependable flow are taken from (Radhika, Firmansyah, \& Hatmoko, 2017), while the water demand is from (Direktorat Bina Penatagunaan Sumber Daya Air, 2016). The higher EFR makes less water available for other water users such as DMI and irrigation.

Figure 5 and Figure 6 show the water balance in Citarum RBT. The EFR from FAO and Q95\% does not differ significantly. In Cimanuk-Cisanggarung RBT, the EFR from FAO is considerably higher than EFR of Q95\%. The irrigation water shortage using EFR of Q95\% is only in December (Figure 7), while if EFR from FAO is apllied, it would be worse, from the month of Juni until December (Figure 8).

In Cisadea-Cibareno RBT at the Southern part of West Java that not yet fully utilized, the water demand for DMI and irrigation is relatively low. This makes no water shortage problem if using the current EFR of 95\% (Figure 9), or a high EFR from FAO in Figure 10 is applied. To conserve the natural condition, the high EFR from FAO is suggested to be applied in the CisadeaCibareno RBT.

\footnotetext{
* Corresponding author: whatmoko@gmail.com
} 


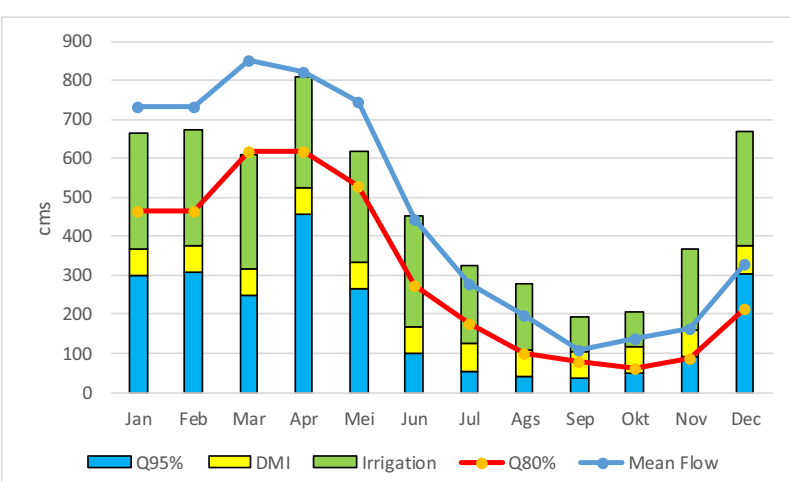

Fig. 5. Water balance of Citarum RBT using EFR of Q95\%

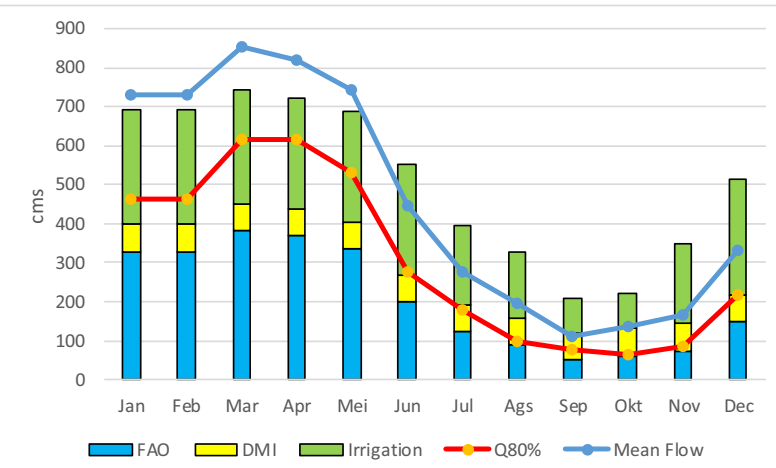

Fig. 6. Water balance of Citarum RBT using EFR from FAO

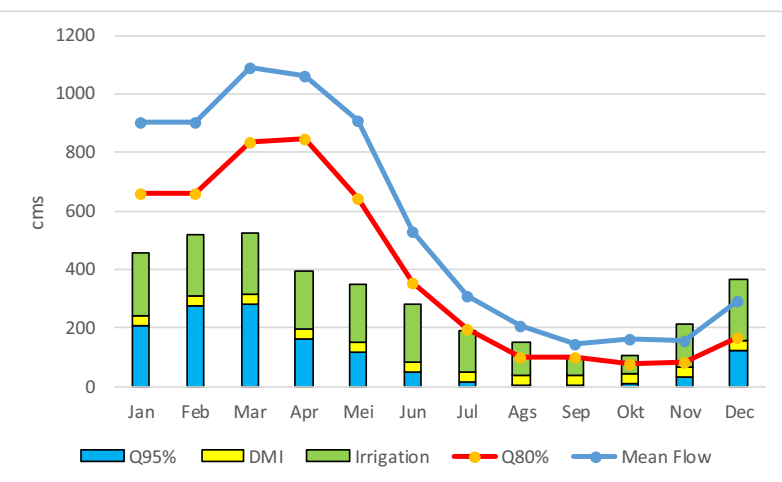

Fig. 7. Water balance of Cimanuk-Cisanggarung RBT using EFR of Q95\%

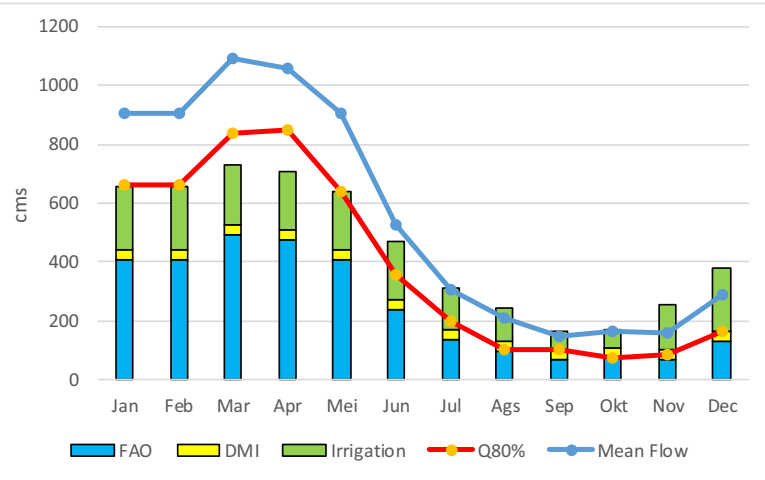

Fig. 8. Water balance of Cimanuk-Cisanggarung river basin territory using EFR from FAO

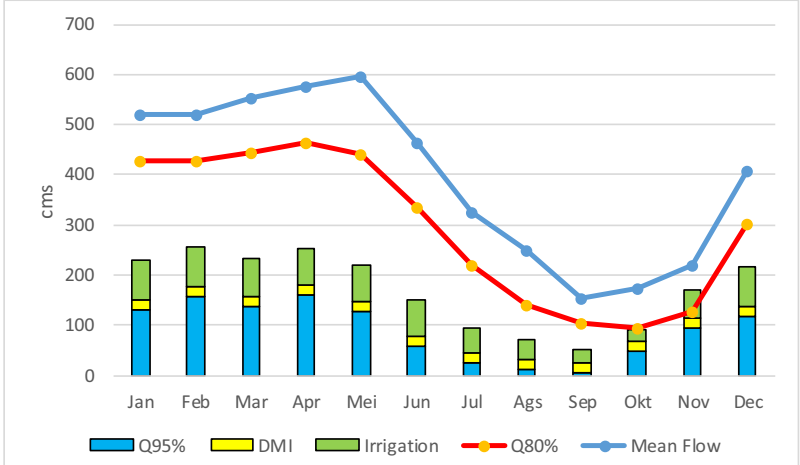

Fig. 9. Water balance of Cisadea-Cibareno RBT territory using EFR of Q95\%

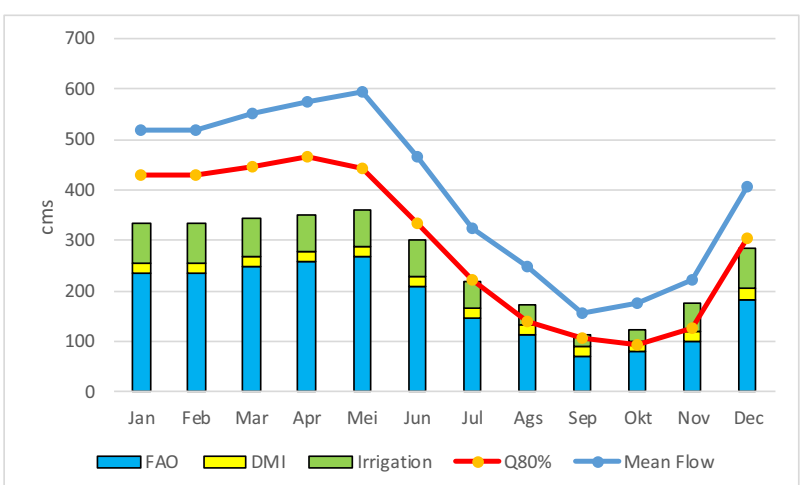

Fig. 10. Water balance of Cisadea-Cibareno RBT using EFR from FAO

\section{Conclusions and Recommendations}

It is concluded that the highest rate of EFR is from FAO in between $40 \%$ to $50 \%$ of the mean flow for rivers in Java. This high EFR is close to the dependable flow of Q95\%, except in the dry season Q95\% is much lower than FAO because of taking the probability of exceedance rather than a fixed percentage.

The relatively high quantity of FAO's EFR FAO is suitable for the rivers in the pristine catchments in the southern part of West Java. However, if it is implemented for the rivers in the northern part of West Java which is heavily populated and maturely developed, conflict with existing water users cannot be avoided. The suggested appropriate EFR for West Java is the dependable flow of Q95\%. The least minimum EFR can be set according to the irrigation standard that is only $5 \%$ of the available flow.

This research is funded by Research Center for Water Resources, Agency of research and Development, Ministry of Public Works Indonesia. Authors wish to express their appreciation to the Management of Experimental Station for Hydrology and Water Management for their support of this research. 


\section{References}

1. Direktorat Bina Penatagunaan Sumber Daya Air. (2016). Penyusunan Peta Ketersediaan Air. Jakarta.

2. Ditjen Pengairan. (1986). Pedoman Studi Proyek Pengairan PSA 01. Jakarta: Departemen Pekerjaan Umum.

3. FAO. (2019). Incorporating environmental flows into "water stress" indicator 6.4.2 - Guidelines for a minimum standard method for global reporting. Rome: Food and Agriculture Organization of United Nations.

4. Goodman, A. S., \& Major, D. C. (1984). Principles of water resources planning. Prentice-Hall, Inc.

5. Pengairan, D. J. (1986). Kriteria Perencanaan Irigasi - Kriteria Perencanaan Bagian Bangunan Utama KP-02. Jakarta: Departemen Pekerjaan Umum.

6. Radhika, Firmansyah, R., \& Hatmoko, W. (2017). Perhitungan Ketersediaan Air Permukaan Di Indonesia Berdasarkan Data Satelit Computation Of Surface Water Availability In Indonesia. Jurnal Sumber Daya Air, 13(2), 115-130. Retrieved from http://jurnalsda_pusair.pu.go.id/index.php/JSDA/arti cle/view/206

7. Shaeri Karimi, S., Yasi, M., \& Eslamian, S. (2012). Use of hydrological methods for assessment of environmental flow in a river reach. International Journal of Environmental Science and Technology, 9(3), 549-558. https://doi.org/10.1007/s13762-0120062-6

8. Sood, A., Smakhtin, V., Eriyagama, N., Villholth, K. G., Liyanage, N., Wada, Y., Dickens, C. (2017). Global environmental flow information for the sustainable development goals. https://doi.org/10.5337/2017.201 